\title{
Re-Imagining the Nation
}

Lessons from the Debates of Immigration in a Settler Society and an Ethnic Nation

Harald Bauder

\author{
CMS 2 (1):9-27 \\ DOI: $10.5117 / C M S 2014.1 . B A U 2$
}

\begin{abstract}
In the context of immigration and settlement, Canada and Germany are often portrayed as opposites: Canada represents a settler society and Germany an ethnic nation. The different approaches and attitudes of the two countries towards immigration can be linked to different historical understandings of nationhood. Canada could not be imagined as a country without its immigrants; immigration is an integral aspect of national identity. Conversely, although Germany has always received immigrants, national identity has historically been conceived in ethnic terms. In this paper, I explore some of the contradictions in Canadian and German immigration debates related to national belonging. For example, Canada's identity as a settler society has long marginalized Indigenous populations, while in German debate the narratives of ethnically-belonging Germans and newly-arriving migrants openly engage with each other. By exploring these contradictions, I develop a perspective of the dialectic of migration and ethnic belonging that can be applied to both Canada and Germany.
\end{abstract}

Keywords: immigration, migration, settler society, ethnic nation, national imagination, Indigenous, nationhood, dialectic, Canada, Germany

\section{Introduction}

In a recent speech on the occasion of the $20^{\text {th }}$ anniversary of the infamous racially-motivated attacks against foreigners in Rostock-Lichtenhagen, the President of the Federal Republic of Germany, Joachim Gauck, said that 
resolving the conflicts between people from different cultures "requires recognizing that our country has now become an immigration country" (Gauck, 2012, my translation). This revelation has been nothing new. In fact, efforts to brand Germany as an immigration country rather than an ethnic nation have long been underway, and German courts and other civic institutions have fostered the social inclusion of immigrants for decades. Yet, politicians and the media continue to debate whether Germany is an immigration country, a non-immigration country, or an integration country (Bauder, 2011b, especially pages 161-181). This ambiguity is related to the fact that national identity is not fixed but developing in light of historical understandings of nationhood (e.g. Anderson, 1991) as well as contemporary material realities of human mobility and membership in the territorial nation state.

Similar to Germany, Canada's national identity and its associated affirmation of immigration is rooted in a historical context of colonialization and contemporary material circumstances of immigration and multiculturalism. Unlike Germany, however, where different models of national and territorial belonging collide in public and political debate, in Canada the dominant understanding of national identity as a settler society has pushed aside an Indigenous model of ethnic belonging.

In this article, I juxtapose Canadian and German understandings of national belonging and debates of immigration. While I build on the existing literature on migration and settlement comparing Canada and Germany (Bauder, 2006b, 2008a, 2011a; Bendel and Kreienbrink, 2008; Reitz et al., 1999; Geißler, 2003; Schmidtke, 2010; Schultze, 1994; Triadafilopoulos, 2004, 2006, 2012; Winter, 2001; ZWH, 2009), I also add to this literature by outlining important contradictions in Canadian and German immigration debates and by interpreting these contradictions in relation to the dialectic of migration and ethnic belonging. My application of dialectics as an analytical framework involves juxtaposing oppositional positions and revealing contradictions. These contradictions are constitutive elements of the formation of identities and understandings of nationhood and belonging.

Phil Triadafilopoulos (2012) has recently argued that Canadian and German policies towards immigration and integration have been converging in light of overarching common values and political principles. This convergence has been the subject of broader academic debate emphasizing the role of universal principles, global human rights, post WWII decolonialization and the universal rejection of racism in the context of migration and settlement policies and practices (e.g. Castles, 2004; Joppke, 2005; Soysal, 
1994). In this article, however, I highlight the lingering historical differences between Canadian and German understandings of nationhood and corresponding attitudes towards immigration. In Canada, the understanding of a settler society has been constructed in dialectical opposition to the Indigenous population; in Germany, the national imagination has tended to exclude immigrants without German ethnic roots. Furthermore, I stress the shortcomings of both countries' approaches towards incorporating migrants and non-migrants into the national imagination. I suggest that both Canadian and German approaches towards immigration harbour irresolvable contradictions. In some respects, the dialectic of immigration debate in German may have surpassed the debate in Canada because the German immigration debate engages the contradictions between migration and ethnic belonging while the Canadian debate does not permit such an engagement (Bauder, 2011a). Canadian media commentators, politicians and diplomats, thus, cannot claim moral superiority in matters of immigration while Indigenous populations remain politically and socially marginalized (e.g. Sterling, 2012).

In this article, I draw on empirical data which I collected in the context of a study of the debate of immigration policy in Canadian and German media. In this study, the particular focus was on the development of the 2002 Canadian Immigration and Refugee Protection Act and the German Immigration Law (Zuwanderungsgesetz), which came into effect in $2005^{1}$. This study revealed dialectics that operates at multiple dimensions: a dialectic of juxtaposing opposing positions in media and public debate; a dialectic of national identity formation in relation to non-belonging populations; and a dialectical relation between material context, law and policy, and public debate (Bauder, 2011b). For the purpose of developing a distinct argument and widen the thematic and temporal scope of this article, I complemented material from this study with academic and "grey" literature as well as legal documents on issues of Indigenous and ethnic belonging.

In the sections that follow, I first provide important background information on the identities of Canada as a settler society and Germany as an ethnic nation. Then, I describe crucial differences between Canada and Germany regarding who is included in and excluded from the national imagination. Thereafter follows a discussion of the dialectical engagement between migration and ethnic belonging in both countries. I conclude with pointing towards potential future politics of belonging. 


\section{Background: Settler Society and Ethnic Nation}

Both Canada and Germany are liberal democracies with 'Western' political traditions and principles and highly-advanced capitalist economies. These commonalities have contributed to the relative convergence of immigration and integration policies and practices in both countries since World War II (Triadafilopoulos, 2012;Joppke, 2005). However, the two countries have also been situated in rather different historical and geopolitical contexts and have framed their national identities in distinct ways. In particular, they long embraced - and to some degree continue to do so - different model of nationhood and national belonging, and have therefore similarly different underlying attitudes towards immigration (Bauder, 2011b). In this section, I briefly review the historical and geopolitical contexts that underlie Canada's and Germany's national imaginations and the corresponding places that immigration occupies in these imaginations.

Canada is often called a "classical" immigration country due to its settlement history. This history includes the establishment of New France in the $16^{\text {th }}$ Century, the arrival of British settlers, and the subsequent geographical expansion towards the Prairies and the West Coast. The settlement of newcomers and the associated processes of colonization, territorial expansion, and economic and demographic development have been intimately intertwined with Canada's national identity as a settler society (Knowles, 1997). While this identity historically involved two (i.e. English and French) founding nations, the Indigenous population was sidelined in the national imagination (Winter, 2007). The identity as a setter society entails that newcomers are not treated as outsiders or foreigners but as new members of society. Corresponding naturalization and citizenship policies have facilitated the formal integration of immigrants into the national polity. The Canada Citizenship Act of 1946, for example, gave first-generation immigrants the opportunity to naturalize after five years of residence in Canada, and it automatically granted Canadian citizenship to all persons born on Canadian soil. This citizenship principle, known as jus soli, ensures that the children of immigrants are included in the Canadian polity, even if their parents chose not become Canadians. These legal practices reflect the identity of Canada as a settler society.

For much of its history, Canada favoured immigration from Europe. Although non-Europeans were needed as labourers, such as the Chinese who built the Canadian Pacific Railway, these migrants were not always welcome as fellow citizens (Knowles, 1997). Not until 1967 did Canadian law remove racial bias and regional criteria from immigrant selection 
procedures. Soon thereafter, Pierre Elliott Trudeau adopted multiculturalism policy in 1971, which Brian Mulroney enshrined into law in 1988. This policy has since recognized the diverse 'ethnic' identities represented in Canadian society (Kelley and Trebilcock, 1998). Multiculturalism further reinforced the idea that Canada is a settler society capable of welcoming newcomers of all origins and backgrounds. The Canadian Multiculturalism Act, however, does not apply to Indigenous institutions of governance (Minister of Justice, 2012), recognizing the distinct nature of Aboriginal identity politics. Aboriginal peoples have typically been excluded from consultations on multiculturalism and "do not see themselves in these policies" (Kunz and Sykes, 2007: 9).

The foundation for today's immigration policies was established with the 1976 Immigration Act, which created different immigrant classes to meet Canada's economic interest, goals of demographic development, and humanitarian obligations under international law. The 2002 Immigration and Refugee Protection Act maintained the general structure of selecting immigrants based on immigrant classes but permitted the government to shift relative weight towards the economic class and thereby facilitate neoliberal, economic-utility driven immigration (Arat-Koç, 1999; Simmons, 1999; Bauder, 2008b). My own empirical research has shown that while differences may exist in opinion of how the economic-utility of immigration can be achieved, participants in political and public debate rarely question that immigration and economic gain for Canada go hand in hand (Bauder, 2011b). This perspective represents an overarching national paradigm in public debate that immigration is a necessary element of Canada's national well-being. The idea that immigration would generally produce harm ${ }^{2}$ and therefore should be blocked altogether is incompatible with Canada's national identity of being a settler society.

Like Canada, Germany is a historical and political construct. Germany's national identity, however, is not founded on immigration. Rather, PanGerman nationalism emerged as a response to the political fragmentation among the states that comprised the Holy Roman Empire and the discontent with the occupation and domination of German-speaking territories by Napoleon Bonaparte's army in the early $19^{\text {th }}$ Century. In opposition to the French nation, which framed national identity in political terms, proponents of the Romantic Movement, such as Johann Gottfried Herder, Johann Gottlieb Fichte, and Ernst Moritz Arndt, associated German nationhood with a language community that shared a common history and destiny. In this way, Germany was established as an ethnic nation. Correspondingly, the unified German state enshrined jus sanguinis into citizenship law in 
1913, which grants membership based on blood lineage, rather than place of birth.

The ethnic identity of Germany excluded ethnic non-Germans from the national imagination. The idea that Germany is the "land of the Germans" (i.e.Deutschland) prevailed throughout the Wilhelmine Empire, the Weimar Republic, the Third Reich and the Federal Republic of Germany, the latter of which otherwise sought to brake with the country's anti-Semitic past and racist barbarism of the Nazi regime. The ethnic principle of national belonging enabled, on the one hand, the integration of almost fifteen million ethnic German refugees who had lived in Eastern Europe but fled to West Germany in the wake of the Soviet occupation and the establishment of communist regimes after World War II (Münz et al., 1999). On the other hand, this principle resulted in the exclusion of roughly 13 million nonGerman migrants who arrived in Germany as "guest workers" between 1955 and 1973. After the discontinuation of the guest-workers program in 1974, many of these workers and their families decided to stay and make Germany their home; yet, many of these families and even their German-born children remained excluded from the national imagination and membership in the national polity (Bade, 1997).

Over time, however, the ethnic identity of Germany came under increasing scrutiny from across the political spectrum. In the late 1970s, the conservative politician Lothar Spät declared that Germany is an "immigration country" (quoted in Meier-Braun, 2002: 46). In the 199os, the left-leaning politician Oskar Lafontaine voiced concern that newly arriving ethnic Germans are privileged over foreigners who have lived in Germany for generations. By 1998, the major political parties embarked on developing competing models for regularized immigration into Germany.

After the 1998 election, the governing Social-Democratic/Green coalition began implementing citizenship and immigration reforms. Citizenship law was altered to incorporate jus soli elements, extending citizenship to the children of established foreign resident in Germany. It also appointed the former president of the lower house of parliament, Rita Süssmuth, as head of a commission to develop the principles of Germany's first immigration law. After years of debate and political bickering - including a delay due to a procedural error in the upper house of parliament and a ruling by Germany's Constitutional Court - an immigration law (Zuwanderungsgesetz) was passed in 2004, which effectively limited, rather than enabled, large-scale immigration into Germany (Storr and Albrecht, 2005). The public debate of this first immigration law illustrates that the German population and media have not entirely come to terms with the idea that Germany is an 
immigration country. For example, unlike in Canada where the notion that immigration will in general produce economic benefits is not questioned, in Germany, public debate of the immigration laws was divided between two opposing positions: one suggesting that immigration should be permitted because the influx of labour and human capital will render Germany's economy more competitive in the global market place; the other proposing that immigration would increase labour competition, put Germans out of work, and should therefore be blocked (Bauder, 2011b). A fundamental debate that seriously considers blocking all immigration would be unfathomable in a settler society like Canada whose identity rests on the positive articulation of immigration.

\section{Inclusion and Exclusion in the National Imagination}

The representations of Canada and Germany as examples of a settler society and an ethnic nation allow me to illustrate important contradictions in the manner in which subjects are included and excluded from the national imagination. While in Canada and Germany migrants and non-migrants are included and excluded based on different criteria, the exclusion of particular groups occurs in both contexts. In this section, I examine the differences in the inclusion in and the dialectical exclusion from the national imagination in light of the material relations that have existed in Canada and Germany.

While Canada has drawn on immigration to frame its national identity, this identity has had an uneasy relationship with Indigenous populations. Although First Nations are now often mentioned as one of the founding peoples in official Canadian documents, this rhetorical and symbolic acknowledgement can be read as a symptom of the political struggles between English and French Canadian interest over multiculturalism rather than an indicator of the material social and political inclusion of Indigenous populations (Winter, 2007). Evidence from my own empirical research suggests that in the contexts of immigration and Canada's identity as a settler society, Indigenous narratives are sidelined. For example, when the Canadian media debated immigration policy reform between the late $1990 \mathrm{~s}$ and mid-200os, an Indigenous narrative was conspicuously absent from the debate (Bauder, 2011b). In fact, one could argue that a "parallax gap" (Žižek, 2006) exists between Indigenous and immigration narratives, which discursively separates two issues that, in fact, are historically and materially closely linked with each other (Bauder, 2011a): the settlement of Canadian 
territory by Europeans has involved the often violent displacement and subordination of Indigenous populations. The ideological justification for this displacement and subordination was supplied by liberal philosophers, such as John Locke (1812[1689]), enabling the colonizers to portray Indigenous political, economic and land-use practices as inferior and thus unworthy of preservation (Arneil, 1994; Tully, 1993). European immigration, settlement and Indigenous displacement have gone hand-in-hand.

Furthermore, Indigenous peoples have made significant contributions to establishing Canada as a country with a settlement identity. Tom Denton (2011, personal communication) remarks with tongue-in-cheek that Indigenous peoples have provided settlement services to immigrants "for over 400 years": after the Pierre Dugua de Monts und Samuel de Champlain arrived in 1604 with their ship and crew on the Isle of St. Croix in the St. Croix River to establish a settlement, members of the Passamaquoddy Nation helped many of the Europeans to survive the harsh winter and later assisted them in moving their settlement across the Bay of Fundy to the Annapolis Basin where the Colonists established Port Royal. In subsequent centuries Indigenous populations continued to play decisive roles in developing the Canadian economy and resource base, warding off foreign intruders, and contributing in many other ways to the well-being of the settlers who lived on the land now encompassing Canada. Despite the intimate connection of Indigenous peoples to Canadian soil ${ }^{3}$, they have remained marginal in the national imagination of Canada as a settler society.

The framing of Canadian national identity reflects the unequal power relations between settlers and their descendants, and Indigenous populations. Since the $17^{\text {th }}$ Century, European military power, economic expansion, population growth and ideas of political organization (e.g. ideas that there could be a nation-state like Canada to begin with) dominated in much of the territory that became Canada. Recent political efforts towards greater social and political inclusion of Indigenous populations have produced mixed results. For example, while multiculturalism policy and the Multiculturalism Act of 1988 recognized Aboriginal rights, it has also refrained from including Aboriginal peoples and institutions. Critics have further alleged that multiculturalism is socially divisive, fails to promote a unifying national identity, and reproduces the European gaze at and toleration of the non-European Other (e.g. Bissoondath, 1994; Day, 2000; Foster, 2007; Harles, 1998). In the context of Canadian multiculturalism, Aboriginal Peoples continue to be depicted as racialized Other while Aboriginal peoples themselves emphasize their historical uniqueness and non-belonging in a society of settlers (Légaré, 1995). While non-European and racialized 
immigrants may claim a place in a settler society composed of diverse origin groups, Indigenous identities challenge the cherished image of Canada as a country of immigrants who came in search of a better future.

In Germany, the national imagination has been construed around a population that passed its German identity from one generation to the next. Even German-born children of foreign migrants, such as the guest workers, have been excluded from full membership in the national imagination. This understanding of nationhood resonates with Indigenous identities in Canada. However, unlike in Canada where Indigenous and immigration narratives have remained discursively separated, in Germany, these two narratives have collided in the context of ongoing debates of the role of migrants in German society.

Until the middle of the $20^{\text {th }}$ Centrury, this collision manifested itself in blatantly Xenophobic and racist government practices and policies. After World War II, the catastrophe of the Holocaust and the genocides committed by the Nazis, the exclusion of ethnic non-Germans continued, albeit without the overt racist language and ideology of the past. For example, after guestworkers were no longer needed, they were labeled "foreigners" (Ausländer), signifying their non-belonging. Likewise, unwanted people seeking refuge were portrayed as "bogus asylum seekers" (Scheinaslylanten) or "economic refugees" (Wirtschaftsflüchtlinge) (Wengeler, 1995). These labels reflect the exclusionary government policies and practices of the late 1970s and $1980 \mathrm{os}$.

Although politically and socially marginalized as "foreigners", these migrants have made enormous contributions to German society and their labour constituted an essential structural component of the German economy (Bauder, 2006b). For most of Germany's modern history, foreign labour has filled seasonal and cyclical labour shortages in agriculture and industry (Bade, 2004). Similarly, the "economic miracle" of post-war recovery was fueled by the guest workers program that facilitated the entry of foreign labour into Germany but politically and socially excluded the very people providing this labour. In recent decades, demands have increased to attract highly-skilled foreign workers to overcome skill shortages in the German labour market and make Germany's economy globally more competitive. I have argued elsewhere that the value of foreign labour lies precisely in the social and political marginalization of the people providing this labour: by not extending political, social and economic rights to foreign workers, they are more exploitable than German citizens and in this way facilitate capital accumulation (Bauder, 2006b).

Like in Canada, the ability to frame national identity in Germany and exclude some groups from this identity is linked to the unequal distribution 
of power. In the German case, however, economic, military and political control rested with a population that embraced a mythology of territorial belonging based on language, ancestry and blood-lineage. Laws and policies towards foreigners have been shaped by the interests representing this population. Throughout much of Germany's national history, newcomers without ancestral German connections were not entitled to belong in German society. In the final decades of the $20^{\text {th }}$ Century, however, political efforts have attempted to rescript Germany's identity to accommodate foreign residents. An interesting dialectical progression in the context of the debate of the immigration law of 2004 involved the representation of Germany first as an "immigration country", followed by the rebuff that Germany remains a "non-immigration country", and the final resolution that Germany is an "integration country." The identity as "integration country" acknowledges the large foreign population whose presence needs to be accommodated in the national imagination, while new immigration can be blocked. In other words, the "integration country" label satisfies both positions that Germany is neither an immigration country nor a non-immigration country (Bauder, 2011b: 161-181).

Yet, the immigration-nation dialectic (Bauder, 2011b) does not end here: the signatories of a recent petition against immigrant exclusion lamented that "Integration presumes that those who work in this country, have children here, and grow old and eventually die here, must adopt a particular code of conduct before they are allowed to belong" (Kritnet, 2011). Although contemporary integration debate and policies in Germany may seek to be accommodating of people with a "migration background" (Migrationshintergrund), these policies continue to reflect unequal relations of power. From this perspective, migration policies and practices in Canada and Germany may be similarly biased and exclusionary - albeit at different ends of the immigration-Indigenous spectrum.

The two case examples of Canada and Germany illustrate how contradictory the relationship between migration and territorial belonging is: migration discourses in both countries "have failed to legitimate the simultaneous inclusion of some 'migrants' (i.e. settlers) and some non'migrants' (i.e. residents born on the national territory), and the exclusion of some 'migrants' (i.e. people deemed unworthy of national membership ${ }^{4}$ ) and some non-'migrants' (i.e. Indigenous peoples) from the national imagination" (Bauder, 2013: 58, emphasis and footnote in original). At the same time, it would be problematic to construe all migrants as colonizers and non-migrants as exploiters of migrants (e.g. Sharma and Wright, 2008-2009). 
These contradictions are impossible to resolve in the context of national imaginations of settler society and ethnic nation.

\section{Dialectics of Migration and Ethnic Belonging}

In both Canada and Germany, migration and ethnic belonging have been constructed as dialectical opposites. German immigration debate has engaged these dialectical opposites and invigorated a discussion that grabbles with the different situations and roles of migrants and ethnic Germans in German society. Certainly, the nature of this discussion has sometimes been uninformed, populist, and occasionally leaped into ethnic and religious essentialisms. Furthermore, the changes to citizenship law and migration policy that have been associated with this discussion are problematic from human-equality and social-justice viewpoints (e.g. Bauder, 2006b, 2011b; Kritnet, 2011). Yet, this discussion has been productive in the sense that engagement with different perspectives of migration and ethnic belonging has occurred. For example, the publication of a controversial book in 2010 by a member of the Executive Board of the Deutsche Bundesbank, Thilo Sarrazin, critiquing Germany's policies towards immigration and Muslim populations residing in Germany was met with fierce opposition from politicians and advocacy groups, who presented equally contested counter arguments for tolerance, integration and democracy (e.g. Kritnet, 2011). Even the very category of the migrant and foreigner as the unwanted Other has been rescripted in this discussion. For example, empirical research has shown that neither the French, who were the adversaries of German nationhood in the $19^{\text {th }}$ Century and the early $20^{\text {th }}$ Century, nor Southern Europeans, who were construed as non-belonging foreigners in the $1970 \mathrm{~s}$ and 1980s, but the non-European Muslim is now the national Other when the media or politicians debate immigration (Bauder, 2011b; Bauder and Semmelroggen, 2009).

In Canada, discourses of migration and ethnic nationhood are not engaging with each other to the same degree as in Germany. On the one hand, Indigenous groups emphasize the distinction between themselves and the federal state representing the settler society (Macklem, 2002). In addition, Canadian politics towards immigration and Indigenous communities follow different strategic approaches, with immigration policies being developed based on social consensus, while policies towards Indigenous communities tend to be divisive and continue to reflect to politics of colonialism (Leo et al., 2007). On the other hand, multiculturalism - which the Canadian state 
has so proudly pioneered - has a fundamentally uneasy relationship with territorial belonging based on ethnicity and blood-lineage.

Multiculturalism and other federal policies, such as Employment Equity legislation, include Indigenous peoples as an ethnic 'minority' group and conflate the experiences of Indigenous peoples with those of other ethnic groups. "White Paper Liberalism" suggests that Indigenous peoples should be protected in a similar way as other ethnic 'minority' groups because they share similar individual rights of equality and freedom (Turner, 2006). These policies neglect the opposing frameworks of national belonging that apply to Indigenous and immigrant populations. Rather than confronting these opposing frameworks head-on and discursively engaging them in the context of debates of immigration and national belonging, contemporary Canadian political debate side-steps the issue by separating this discourses of immigration and Indigeneity (Bauder 2011a).

The Indigenous and settler frameworks of belonging that co-exist in Canada must not be essentialzed; they are political constructs that have enabled both ethnic and settler groups to pursue their material and political interests and claim geographical territory. My point is that these frameworks should not remain discursively separated through a parallax gap that obscures the material relationship between migration, settlement, and the displacement and subordination of Indigenous peoples (Bauder, 2011a).

Recent attempts have been made to bridge this parallax gap. For example, the Assembly of First Nations (2005) passed a resolution demanding

to freeze all immigration coming into Canada until the federal government addresses, commits, and delivers resources to First Nations to improve the housing conditions, education, health and employment in First Nations communities and that the federal government acknowledge and agree they are bringing immigrants into our lands and using our resources without our consent.

Similarly, the federal government has begun in 2012 to include representatives of the Assembly of First Nations and the Congress of Aboriginal Peoples in its public consultations on immigration targets (Cheadle, 2012). Indigenous concerns that were articulated in the consultations related mostly to the admission of temporary foreign workers who compete with Aboriginal youth for jobs; they stopped short of voicing a more fundamental critique of the settler paradigm of belonging. Nevertheless, an expansion of such consultations to include more substantial debate of immigration policy and the national imagination would offer the possibility to narrow if 
not close the existing parallax gap. Although such a dialectical engagement is a discomforting political process, as the German debate of immigration illustrated, it would be an important step towards eventually overcoming the antagonistic claims to territorial belonging represented by the models of the settler society and ethnic nation. The recent Idle No More (http://idlenomore.ca) protests and the public responses to these protests (e.g. Coyle, 2013; Saunders, 2013) have demonstrated that the opposing Indigenous and settler narratives of belonging remain deeply entrenched and deadlocked in the minds of their proponents.

\section{Conclusion}

In Germany, Canada is often presented as a model of successful immigration and integration policy. For example, the initial version of the immigration law that was tabled in German parliament in 2001 contained a Canadianstyle points system to attract skilled workers. Although the final version of the law did not include a points system because the pendulum of public and political opinion had swung back towards protectionism of the German labour market by the time the law passed both houses of parliament in 2004 (Bauder, 2011b), the initial consideration of the points system signifies that the Canadian model of economic-utility driven immigration was perceived as worthy of imitation. Similarly, the German media and public commentators often present the Canadian settlement system as a role model for Germany, and German politicians frequently visit Canada for guidance and inspiration on effective integration policies (see Introduction to this special issue). Within the context of an immigrant society that is not only open to newcomers but also welcomes newcomers in the community and the national imagination, Canada indeed has had an edge over Germany.

Nevertheless, Canadians should refrain from claiming moral superiority in matters of immigration and integration. In particular, the discursively separated issues of immigration and Indignity have, in my eyes, not been adequately addressed. While in Germany public debate on immigration has engaged with the different roles of ethnic Germans, foreigners and newcomers in the national imagination, a similar engagement between immigration and Indigenous narratives rarely occurs in Canadian debate. Simply acknowledging diversity is not enough. For example, the "visible minority" category that was established with Employment Equity legislation includes Aboriginal peoples as a group that is distinct from Canada's European-origin population, but it does not address the fundamentally different understand- 
ings of nationhood and belonging between the descendants of settlers, immigrants and Indigenous peoples. Instead, it treats racialized Aboriginals similar to racialized immigrant groups. Recent policy developments, such as the federal government's effort to include Indigenous communities in the consultation of immigration targets, signify a movement in the right direction. Expanding the discursive and political engagement between immigration and Indigenous understandings of territorial belonging, and re-connecting the corresponding narratives and policies would foster reconciliation between the populations that now occupy Canadian land.

Neither Canada nor Germany has yet been able to transcend divisive understandings of territorial belonging that are represented by the opposing models of settler society and ethnic nation. A critical political agenda may entail rescripting migrant and Indigenous subjectivities into a unifying collective identity (Anderson, et al. 2009; Bauder, 2013). Along these lines, recent scholarship has questioned whether the territorial nation state is indeed the entity under which such unifying identities can be achieved. After all, the nation state has historically been an instrument for reproducing the unequal power relations between settlers and Indigenous populations, and between populations with ancestral claims to territory and newcomers (Bauder, 2006a). Radical and critical scholarship has therefore sought to fundamentally rethink the relationship between migration, territorial belonging, and the nation state. While the nation state reflects the contemporary geopolitical condition of how migration flows are regulated, how migration is discursively framed, and how polities are territorially organized (e.g. Sassen, 2006; Sharma, 2006; Taylor, 1994), this scholarship is critiquing the taken-for-granted frame of the nation state when researchers, political actors, the media and the public discuss human mobility and territorial belonging (Anderson et al., 2009; Bauder, 2006a; Sharma, 2006; Wimmer and Glick Schiller, 2002). Similarly, critical geographers have been warning against essentializing the national scale (e.g. Delaney and Leitner, 1997; Marston, 2000; Mountz and Hyndman, 2006). For example, territorial belonging can be expressed at the urban scale, which may be better suited to accommodate migrants, non-migrants and Indigenous populations alike (e.g. Bauböck, 2003; Varsanyi, 2006). Grass-roots organizations, such No One is Illegal, are declaring that "Canada is illegal" (NOII, 2011: no page) and are pleading for solidarity between margnizalized immigrant and Indigenous populations at the urban scale (Bauder, 2013). In this article, however, I did not pursue such arguments. Rather, I emphasized national identity as a historical and political construct, and explored the dialectical relationship between the concepts of migration and belonging. 
Assuming that the nation state remains the dominant political configuration for the foreseeable future, the dialectical resolution of the two models of belonging will not be accomplished by continuing to embrace national models of setter society and ethnic nation. In the same speech, which I quoted in the beginning of this article, Joachim Gauck (2012, my translation) also remarked: "We will not be able to achieve an entirely unified society, but we can achieve one based on solidarity." Similar rhetoric is echoed by the organizers of the conference "Encounters in Canada: Contrasting Indigenous and Immigrant Perspectives" held in Toronto in May 2013, featuring former Prime Minister Paul Martin as the keynote speaker. This conference was a rare occasion, which brought together settler and ethnic narratives of national belonging. The conference description suggests that "respect and trust can be fostered through shared difference" aiming to "build bridges [between] Indigenous peoples, descendants of early settlers, and more recent immigrants and refugee communities" (Dalton, 2013). If the nation state persists as the dominant framework of territorial belonging - and this would be the framework that Gauck as the President and Paul Martin as a former Prime Minister of two nation states embrace - then solidarity between newcomers, the descendants of settlers, and people tied to territory through ancestry will be necessary to bridge the parallax gap that exists in both Canada and Germany.

\section{Acknowledgements}

The open-access publication of this article is supported by a grant from the Office of the Dean of Arts, Ryerson University and Ryerson University Library. The research was funded by the Social Sciences and Humanities Research Council of Canada. I thank Peter Scholten and two reviewers for excellent comments.

\section{Notes}

1. A detailed description of the research design is available in the appendix of Immigration Dialectic (Bauder 2011b: 211-223).

2. While Canadian public debate endorses immigration in general, it does not support all immigration. Narratives of bogus refugees, cue jumpers, or safe haven for terrorists exemplify representations of unwanted migrants (Bauder, 2011b).

3. Ironically, the jus soli principle of citizenship, which Canada follows, associates membership in the national community with being born in Canadian territory, i.e. being born on traditional Indigenous soil. 
4. E.g. 'migrants' denied entry into the national territory and temporary residents denied permanent residency.

\section{References}

Anderson B. (1991). Imagined communities: reflections on the origin and spread of nationalism. Revised edition. London: Verso.

Anderson B., Sharma N. and Wright C. (2009). Why no borders? Refuge 26 (2), 5-18.

Arat-Koç S. (1999). Neo-liberalism, state restructuring and immigration: changes in Canadian policies in the 1990 Journal of Canadian Studies 34 (2), 31-56.

Arneil B. (1994). Trade, plantations, and property: John Locke and the economic defense of colonialism. Journal of the History of Ideas 55 (4), 591-6o9.

Assembly of First Nations (2005) Resolution no. 49, Regina. Available at: http://64.26.129.156/ article.asp?id=1946 (accessed 30 December 2012)

Bade K. J. (ed.) (1997). Fremde im Land. Osnabrück: Universitätsverlag Rasch.

Bade K. J. (2004). Sozialhistorische Migrationsforschung. Vol. 13, Studien zur historischen Migrationsforschung, ed. Michael Bommes and Jochen Oltmer, Göttingen: V \& R Unipress.

Bauböck R. (2003). Reinventing urban citizenship. Citizenship Studies 7 (2), 139-16o.

Bauder H. (2006a). And the flag waved on: immigrants protest, geographers meet in Chicago. Environment and Planning $A$ 38, 1001-1004.

Bauder H. (2006b). Labor movement: how migration regulates labor markets. New York: Oxford University Press.

Bauder H. (2008a). Kanada: Zuwanderungsmodell für Deutschland? Geographische Rundschau $60(2), 48-50$.

Bauder H. (2008b). The economic case for immigration: neoliberal and regulatory paradigms in Canada's press. Studies in Political Economy 82 (Autumn), 131-152.

Bauder H. (2011a). Closing the immigration-Aboriginal parallax gap. Geoforum 42, 517-519.

Bauder H. (2011b). Immigration dialectic: imagining community, economy and nation. Toronto: University of Toronto Press.

Bauder H. (2013). Nation, 'migration' and critical practice. Area 45 (1), 56-62.

Bauder H. and Semmelroggen J (2009). Immigration and imagination of nationhood in German Parliament. Nationalism \& Ethnic Politics 15 (1): 1-26.

Bendel P. and Kreienbrink A. (eds.) (2008). Kanada und Deutschland:Migration und Integration im Vergleich. Nürnberg, De: Bundesamt für Migration und Flüchtlinge.

Bissoondath N. (1994). Selling illusions: The cult of multiculturalism in Canada. Toronto: Penguin Books.

Castles, S. (2004). Why migration policies fail. Ethnic and Racial Studies 27 (2), 205-227.

Cheadle B. (2012). First Nations consulted on 2013 immigration targets as Tories break new ground. Vancouver Sun, September 2o. Available at: http://www.vancouversun.com/business/First+Nations+consulted+2013+immigration+targets+Tories+break+ground/7275078/ story.html (accessed 30 December 2012).

Coyle J. (2013). Idle No More: a chance to repair a sad legacy. The Toronto Star, 12 January. Available at: www.thestar.com/printarticle/1314325 (accessed January 15, 2013).

Dalton J. E. (2013). Encounters in Canada: contrasting Indigenous and immigrant perspectives. Announcement on POLCAN@listes.ulaval.ca (received January 12, 2013).

Day R. J. F. (200o). Multiculturalism and the history of Canadian diversity. Toronto, University of Toronto Press. 
Delaney D. and Leitner H. (1997). The political construction of scale. Political Geography 16 (2), 93-97.

Denton T. (2011). Personal communication. 31 January.

Foster C. (2007). Blackness and modernity: the colour of humanity and the quest for freedom. Montreal and Kingston: McGill-Queen's University Press.

Gauck J. (2012). Speech at the memorial ceremony of the $20^{\text {th }}$ Anniversary of the anti-foreigner riots in Rostock-Lichtenhagen, 26. August. Available at: http://www.bundespraesident.de/ SharedDocs/Reden/DE/Joachim-Gauck/Reden/2012/o8/120826-Rostock.html (Accessed ${ }_{31}$ October 2012)

Geißler R. (2003). Multikulturalismus in Kanada - Modell für Deutschland? Aus Politik und Zeitgeschichte 26, 19-25.

Harles J. (1998). Multiculturalism, national identity, and national integration: the Canadian case. International Journal of Canadian Studies 17, 217-248.

Joppke, C. (2005). Selecting by origin: ethnic migration in the liberal state. Cambridge/Mass.: Harvard University Press.

Kelley N. and Trebilcock M.J.(1998). The making of the mosaic: a history of Canadian immigration policy. Toronto: University of Toronto Press.

Knowles V.(1997). Strangers at our gates: Canadian immigration and immigration policy, 1540-1997. Toronto: Dundrun Press.

Kunz J. L. and Sykes S. (2007). From mosaic to harmony: multicultural Canada in the $21^{\text {st }}$ Century - Results of regional roundtables. Ottawa: Government of Canada, Policy Research Initiative.

Légaré E. I. (1995). Canadian multiculturalism and Aboriginal people: negotiating a place in the nation. Identities 1 (4), 347-366.

Leo C., August M. and Rogers M. D. (2009). Is the federal government dividing the Aboriginal community? Can it stop? A Winnipeg case study. Paper prepared for the Annual Meeting of the Canadian Political Science Association, Ottawa. Available at: http://blog.uwinnipeg. ca/ChristopherLeo/Cohesion.pdf (accessed 30 December 2012).

Macklem P. (2002). Indigenous difference and the constitution in Canada. University of Toronto Press, Toronto.

Marston S. (2000). The social construction of scale. Progress in Human Geography 24 (2), 219-242.

Meier-Braun K.-H. (2002). Deutschland, Einwanderungsland. Frankfurt am Main: Surkamp Verlag.

Minister of Justice (2012). Canadian Multiculturalism Act. Available at: http://laws-lois.justice. gc.ca/PDF/C-18.7.pdf (last accessed 30 December 2012).

Münz R., Seifert W. and Ulrich R.E. (1999). Zuwanderung nach Deutschland:Strukturen, Wirkungen, Perspektiven. 2nd ed. Frankfurt am Main: Campus Verlag.

Mountz A. and Hyndman J. (2006). Feminist approaches to the global intimate. Women's Studies Quarterly 34 (1/2), 446-463.

Netzwerks Kritische Migrations- und Grenzregimeforschung (Kritnet) (2011) Democracy not integration. Available at: http://demokratie-statt-integration.kritnet.org/demokratie-stattintegration_en.pdf (accessed 26 October, 2012)

No One Is Illegal (2011). On the justice of tearing down fences and dismantling borders. Thursday, April 28. Available at: http://noii-ottawa.blogspot.com/ (accessed Jan. 30, 2012).

Reitz J. G., Frick J. R., Calabrese T. and Wagner G. (1999). The institutional framework of ethnic employment disadvantage: a comparison of Germany and Canada. Journal of Ethnic and Migration Studies 25 (3), 397-443.

Sassen S. (2006). Territory, authority, rights: from medieval to global assemblages. Princeton, NJ: Princeton University Press. 
Saunders D. (2013). What kind of nation is a first nation? We need to decide. The Globe and Mail, 12 January. Available at: http://www.theglobeandmail.com (accessed Jan. 12, 2013)

Sharma N. (2006). Home economics: nationalism and the making of migrant workers in Canada. Toronto: University of Toronto Press.

Sharma N. and Wright C. (2008-2009). Decolonizing resistance, challenging colonial states. Social Justice 35 (3), 120-138.

Schmidtke O. (2010). Einwanderer als Ware: Wie die Marktlogik Migranten aussortiert. Blätter für deutsche und internationale Politik 10, 51-57.

Schultze G. (ed.) (1994). Einwanderungspolitik Kanada's und der USA: Beispiele für die Bundesrepublik Deutschland? Bonn, DE: Forschungsinstitut der Friedrich-Ebert-Stiftung, Apteilung. Arbeits- und Sozailforschung.

Simmons A. B. (1999). Economic integration and designer immigrants: Canadian policy in the 199os. In Castro M J (ed.) Free markets, open societies, closed borders? Trends in international migration and immigration policy in the Americas (pp. 53-69) Miami, Florida: North-South Center Press.

Soysal Y. N. (1994). Limits of citizenship: migrants and postnational membership in Europe. Chicago: University of Chicago Press.

Sterling H. (2012). Two styles of welcoming immigrants. Calgary Herald, 21 December. Available at: http://www.calgaryherald.com (accessed Dec. 21, 2012)

Storr C. and Albrecht R. (2005) Kommentar zum Zuwanderungsgesetz, Stuttgart: Boorberg Verlag.

Taylor P. J. (1994). The state as container: territoriality in the modern world-system. Progress in Human Geography 18 (2), 151-162.

Triadafilopoulos P. (2004). Building walls, bounding nations: migration and exclusion in Canada and Germany, 1870 1939. Journal of Historical Sociology 17 (4), 385-427.

Triadafilopoulos P. (2006). A model for Europe? An appraisal of Canadian integration policies. In Baringhorst S, Hunger U and Schönwälder K (eds.) Politische Steuerung von Integrationsprozessen: Intentionen und Wirkungen (pp. 79-94). Wiesbaden, DE: VS Verlag für Sozialwissenschaften.

Triadafilopoulos P. (2012). Becoming multicultural: Immigration and the politics of membership in Canada and Germany. Vancouver, BC: UBC Press.

Tully J. (1993). An Approach to Political Philosophy: Locke in Context., Cambridge, UK: Cambridge University Press.

Turner D. (2006). This is not a peace pipe: towards a critical Indigenous philosophy. Toronto: University of Toronto Press.

Varsanyi M. W. (2006). Interrogating "urban citizenship" vis-à-vis undocumented migration. Citizenship Studies 10 (2), 229-249.

Wengeler M. (1995). Multikulturelle Gesellschaft oder Ausländer raus? Der sprachliche Umgang mit der Einwanderung seit 1945. In Stötzel G, Wengeler M and Böke K (eds.) Kontroverse Begriffe: Geschichte des öffentlichen Sprachgebrauchs in der Bundesrepublik Deutschland (pp. 711-749). Berlin: Walter de Gruyter.

Wimmer A. and Glick Schiller N. (2002). Methodological nationalism and beyond: nation-state building, migration and the social sciences. Global Networks 2 (4), 301-334.

Winter E. (2001). National unity versus multiculturalism? Rethinking the logic of inclusion in Germany and Canada. International Journal of Canadian Studies - Revue Internationale d'études Canadiennes 24, 171-195.

Winter E. (2007). Bridging unequal relations, ethnic diversity, and the dream of unified nationhood: multiculturalism in Canada. Zeitschrift für Kanada-Studien 1, 38-57. 
Zentralstelle für die Weiterbildung im Handwerk (ZWH) (2009) To Canada migration nach Deutschland. Düsseldorf.

Žižek S. (2006). The parallax view. Cambridge, Massachusetts: The MIT Press.

\section{About the author}

Harald Bauder, Department of Geography and Graduate Program in Immigration and Settlement Studies, Ryerson University.

E-mail: hbauder@ryerson.ca

Harald Bauder is Professor of Geography at Ryerson University and the Academic Director of the Ryerson Centre for Immigration and Settlement (RCIS). His most important books include Immigration Dialectic: Imagining Community, Economy and Nation (University of Toronto Press, 2011) and Labor Movement: How Migration Regulates Labor Markets (Oxford University Press, 2006).

\section{$(1) \Theta$}

Bauder / Amsterdam University Press.

This is an Open Access article distributed under the terms of the Creative Commons Attribution License (http:// creativecommons.org/licenses/by/2.o), which permits unrestricted use, distribution, and reproduction in any medium, provided the original work is properly cited. 